\title{
Polypeptide Synthesis and Phosphorylation in Epstein-Barr Virus-Infected Cells
}

\author{
ROBERT J. FEIGHNY, MICHAEL P. FARRELL, AND JOSEPH S. PAGANO
}

Cancer Research Center, Department of Bacteriology and Immunology, and Department of Medicine, School of Medicine, University of North Carolina at Chapel Hill, Chapel Hill, North Carolina 27514

\begin{abstract}
Epstein-Barr virus superinfection of the human lymphoblastoid cell line Raji, a Burkitt lymphoma-derived line that contains Epstein-Barr virus genomes in an episomal form, results in the sequential synthesis of 29 detectable proteins, which range in molecular weight from approximately 155,000 to 21,000 , and in the shutoff of the bulk of host protein synthesis within 6 to $9 \mathrm{~h}$ after infection. There are three classes of virus-induced proteins; these are an early class, consisting of eight proteins synthesized by $6 \mathrm{~h}$ postinfection, an intermediate class, containing two proteins synthesized $9 \mathrm{~h}$ postinfection, and a late class, consisting of five proteins synthesized $12 \mathrm{~h}$ postinfection. In addition, there is a fourth class of polypeptides, called persistent, that are found both before and after superinfection. The rates of synthesis of the proteins fall into three patterns; these are pattern $A$, in which the rate of synthesis decreases, pattern $B$, in which the rate of synthesis remains steady, and pattern $C$, in which the rate of synthesis increases after the initial appearance of the polypeptide. Both 9-(2-hydroxyethoxymethyl)guanine (acyclovir) and phosphonoacetic acid inhibit the appearance of one intermediate protein and at least three late proteins. Seven polypeptides are phosphorylated at different times after infection.
\end{abstract}

Biochemical studies with Epstein-Barr virus (EBV) have lagged behind studies with the other herpesviruses because of the lack of a reproducible infection system. The structural proteins of the viruses from the extracellular fluids of two virus-producing cell lines (HR-1 and B95-8) have been examined (4). However, there has been little work on the appearance of either virion or nonstructural proteins induced in infected cells. This deficiency is due partly to the inconsistent results obtained with the only EBV infection system available, namely, superinfection of the non-virus-producing Raji cell line with virus from the virus-producing P3HR-1 cell line.

Treatment of P3HR-1 with 12-O-tetradecanoylphorbal-13-acetate $(9,15)$ increases the yield of virus sufficiently so that it is possible to infect Raji cells at a relatively high multiplicity. Under these conditions most of the host cell protein synthesis is inhibited, minimizing the background of cellular protein synthesis, and virus-induced proteins are detected reproducibly. Shutoff of cellular protein synthesis after superinfection was also shown by Bayliss and Nonoyama (2).

In this report we show the shutoff of host protein synthesis, the persistence of some proteins present before infection of Raji cells, the appearance of virus-induced proteins, and the dependence of induced protein synthesis on vi- rus DNA replication. We also show the course of phosphorylation of some of these proteins in the infected cells.

\section{MATERIALS AND METHODS}

Cells and virus. Two Burkitt lymphoma-derived cell lines, Raji and P3HR-1, were maintained as previously described (12). Extracellular virus was purified from P3HR-1 cells 5 days after addition of 12-O-tetradecanoylphorbol-13-acetate at a concentration of 20 $\mathrm{ng} / \mathrm{ml}$ (15) by the procedure of Adams (1). Superinfection of Raji cells with EBV was as described by Shaw et al. (12) and Lin et al. (9). At least 90\% of the cells showed early antigen after infection.

Radiolabeling of virus-induced proteins. Cells were radiolabeled with $\left.{ }^{[35} \mathrm{S}\right]$ methionine by one of the following methods. For continuous labeling of proteins, $\left.{ }^{26} \mathrm{~S}\right]$ methionine was added $6 \mathrm{~h}$ postinfection at a concentration of $10 \mu \mathrm{Ci} / \mathrm{ml}$ in RPMI 1640 medium. The virus-infected and mock-infected cells were harvested $30 \mathrm{~h}$ postinfection. Protein was determined by the method of Lowry et al. (10), and equal amounts of protein were subjected to gel electrophoresis.

For pulse-labeling of proteins, samples of infected and mock-infected cells containing $2.5 \times 10^{6}$ cells were removed and pelleted. Each pellet was suspended in $1.0 \mathrm{ml}$ of medium containing $200 \mu \mathrm{Ci}$ of $\left[{ }^{35} \mathrm{~S}\right]$ methionine for $15 \mathrm{~min}$ at $37^{\circ} \mathrm{C}$. The cells were centrifuged again and fractionated as described below.

For pulse-chase experiments $6 \times 10^{6}$ cells were pelleted $7 \mathrm{~h}$ after infection and incubated for $15 \mathrm{~min}$ at $37^{\circ} \mathrm{C}$ in $1.0 \mathrm{ml}$ of medium containing $200 \mu \mathrm{Ci}$ of 
$\left[{ }^{35} \mathrm{~S}\right]$ methionine. The cells were pelleted and washed twice with medium warmed to $37^{\circ} \mathrm{C}$ without $\left[{ }^{35} \mathrm{~S}\right] \mathrm{me}$ thionine. After washing, the cells were suspended in $40 \mathrm{ml}$ of medium. At the times indicated below, $10 \mathrm{ml}$ of cells was removed and fractionated.

For prelabeling of uninfected cells, $1.5 \times 10^{7}$ cells were pelleted and suspended in $50 \mathrm{ml}$ of RPMI 1640 medium containing $\left[{ }^{35} \mathrm{~S}\right]$ methionine at a concentration of $2 \mu \mathrm{Ci} / \mathrm{ml}$. After $24 \mathrm{~h}$ at $37^{\circ} \mathrm{C}$, the medium was removed, the cells were washed once, and $50 \mathrm{ml}$ of warmed medium without $\left[{ }^{35} \mathrm{~S}\right]$ methionine was added. The cells were then incubated at $37^{\circ} \mathrm{C}$ for $1 \mathrm{~h}$, after which $1.2 \times 10^{7}$ cells were pelleted and infected. After infection, the cells were suspended in $50 \mathrm{ml}$ of medium. At the times indicated below, $10 \mathrm{ml}$ of cell suspension was removed and fractionated.

For examination of phosphoproteins, cells were pulse-labeled as described above, except that $\left[{ }^{32} \mathrm{P}\right]$ orthophosphoric acid at a concentration of $500 \mu \mathrm{Ci} / \mathrm{ml}$ was used in phosphate-free medium.

Fractionation of cells. Fractionation of cells into cytoplasmic and nuclear material was performed as follows. At the times indicated below, cells were pelleted and then washed twice with cold phosphatebuffered saline $(0.01 \mathrm{M}$ phosphate buffer, $\mathrm{pH} 7.4,0.15$ $\mathrm{M} \mathrm{NaCl}$ ). After washing, cells were suspended in $\mathbf{0 . 2}$ $\mathrm{ml}$ of reticulocyte standard buffer $(0.01 \mathrm{M}$ Tris-hydrochloride, $\mathrm{pH} 8,10 \mathrm{mM} \mathrm{NaCl}, 1.5 \mathrm{mM} \mathrm{MgCl}_{2}$ ) containing $1 \%$ Nonidet P-40. After $10 \mathrm{~min}$ at $0^{\circ} \mathrm{C}$, the nuclei were sedimented by centrifugation at $750 \times g$ for 5 min at $4^{\circ} \mathrm{C}$. The nuclear pellet was suspended in 0.2 $\mathrm{ml}$ of $0.05 \mathrm{M}$ Tris-hydrochloride, $\mathrm{pH} \mathrm{6.8}$. Both the cytoplasm and the nuclei were then solubilized in gel sample buffer. In those experiments in which counts per minute were determined, a small sample of whole cells was precipitated by adding cold $10 \%$ trichloroacetic acid. The precipitate was passed through a Whatman GF/G filter, washed two times with cold 5\% trichloroacetic acid, and counted.

Gel electrophoresis. For all experiments except the pulse-chase experiment, equal amounts of protein, as determined by the procedure of Lowry et al. (10), were analyzed by slab polyacrylamide gel electrophoresis in 7.5\% gels, using the method of Laemmli (7). The molecular weights of the proteins were estimated by the procedure of Weber and Osborn (14), using $\beta$ galactosidase (molecular weight, 135,000), phosphorylase $A(92,000)$, bovine serum albumin $(67,000)$, and ovalbumin $(43,000)$ as standard markers. For the pulse-chase experiment, equal numbers of acid-insoluble counts per minute were added to the gel.

After electrophoresis, gels were stained with $0.1 \%$ Coomassie brilliant blue in $25 \%$ methanol-7\% acetic acid and then dried with an SE540 slab gel dryer (Hofer). Dried gels were exposed to Kodak X-Omat R film at $-70^{\circ} \mathrm{C}$. In some experiments, gels were prepared for fluorography by the method of Bonner and Laskey (3) and exposed at $-70^{\circ} \mathrm{C}$.

Inhibition of viral DNA replication. The drugs acyclovir [ACV; [9-(2-hydroxyethoxymethyl)guanine] and phosphonoacetic acid (PAA) were added to the cells after a 2-h absorption of virus to cells. ACV was used at a final concentration of $100 \mu \mathrm{M}$, and PAA was used at a concentration of $100 \mu \mathrm{g} / \mathrm{ml}$. At $6 \mathrm{~h}$ after addition of the drug, cells were labeled continuously with $\left[{ }^{35} \mathrm{~S}\right]$ methionine as described above. Cell pellets were solubilized and subjected to gel electrophoresis.

Materials. $\left[{ }^{35} \mathrm{~S}\right]$ methionine (100 to $400 \mathrm{Ci} / \mathrm{mmol}$ ) and $\left[{ }^{32} \mathrm{P}\right]$ orthophosphoric acid were obtained from New England Nuclear Corp. The molecular weight standards were from Sigma Chemical Co. ACV was a gift from the Burroughs Wellcome Co. PAA was purchased from Richmond Organics.

\section{RESULTS}

Inhibition of protein synthesis after superinfection. At $3 \mathrm{~h}$ after superinfection of Raji cells with EBV, there was an increased rate of protein synthesis (Fig. 1). This stimulation appeared to be the result of superinfection since there was a smaller increase at $3 \mathrm{~h}$ in the mockinfected cells. The rate of protein synthesis in the infected cells then decreased.

The decreased rate of protein synthesis was caused by the shutoff of the synthesis of most host cell proteins. When cells were labeled continuously from 10 to $30 \mathrm{~h}$ after infection, the infected cells incorporated only $10 \%$ of the label

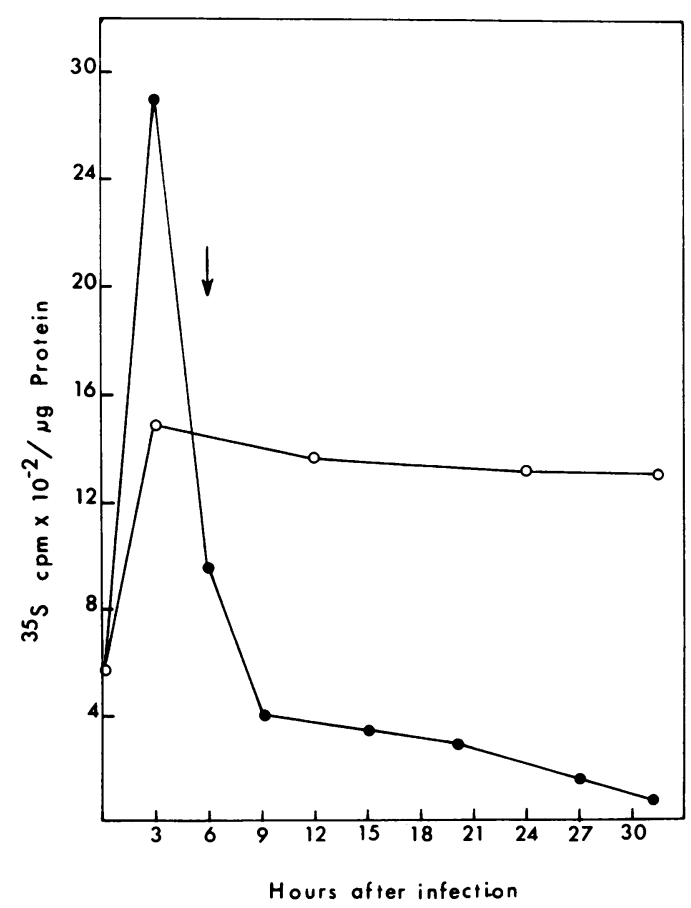

FIG. 1. Rates of protein synthesis after infection of Raji cells with EBV. Cells were pulse-labeled for 15 min at the indicated times after infection, and acidinsoluble counts per minute per microgram of protein were determined by trichloroacetic acid precipitation of samples. Arrows indicate time of appearance of first virus-induced proteins. Symbols: 0 , infected cells; $\bigcirc$, mock-infected cells. 
found in mock-infected cells (data not shown). Analysis of proteins made under these conditions revealed the absence of most host proteins (Fig. 2).

Proteins synthesized after superinfection. When cells were pulse-labeled for $15 \mathrm{~min}$ at varying times after superinfection, 29 proteins were identified (Table 1). Of these proteins, 15 appeared only after superinfection, and 14 were present before infection. Proteins that were present in uninfected cells and remained detectable throughout infection are termed persistent. This was the predominant class late in infection. The induced proteins were grouped into three classes, depending upon the time of initial synthesis. The first class to appear was the early

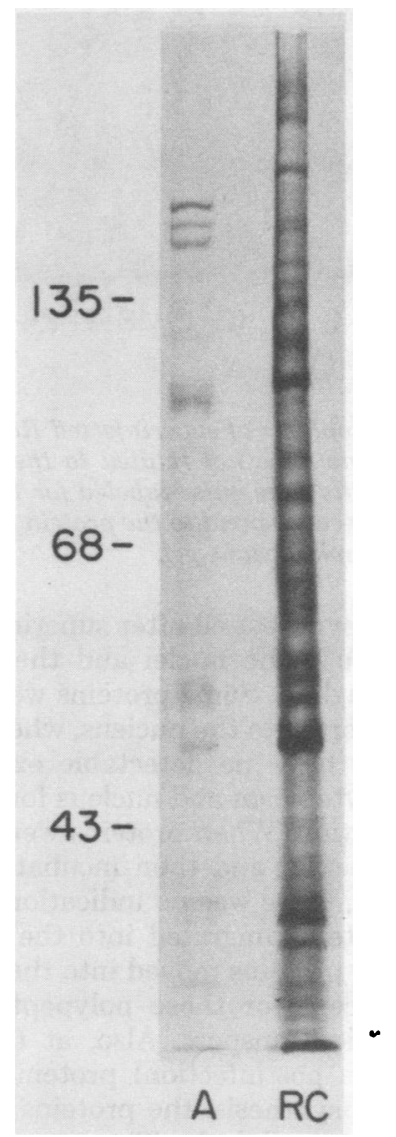

Fig. 2. Shutoff of host protein synthesis by superinfection of Raji cells with EBV. Cells were labeled continuously from 6 to $30 \mathrm{~h}$ after infection with ${ }^{35}$ S]methionine. The cells were harvested and applied to the gel as described in the text. Lane $A$, Superinfected Raji cells; lane RC, mock-infected Raji cells. Numbers on the left are molecular weights of markers $\left(\times 10^{3}\right)$.
TABLE 1. Proteins synthesized after infection of Raji cells with $E B V$

\begin{tabular}{|c|c|c|c|c|c|}
\hline Protein & $\begin{array}{l}\text { Mol wt } \\
\left(\times 10^{3}\right)\end{array}$ & $\begin{array}{l}\text { Time of } \\
\text { appear- } \\
\text { ance }^{a}\end{array}$ & $\begin{array}{c}\text { Intracel- } \\
\text { lular loca- } \\
\text { tion }^{b}\end{array}$ & $\begin{array}{l}\text { Pattern } \\
\text { of syn- } \\
\text { thesis }^{c}\end{array}$ & $\begin{array}{c}\text { Effect of } \\
\text { ACV and } \\
\text { PAA }\end{array}$ \\
\hline 1 & 155 & I & $\mathbf{N}$ & $\mathbf{B}$ & \\
\hline 2 & 145 & I & $\mathbf{N}$ & $\mathbf{B}$ & Inhibition \\
\hline 3 & 140 & $\mathbf{E}$ & $C \& N$ & $\mathbf{A}$ & \\
\hline 4 & 125 & $\mathbf{E}$ & C & $\mathbf{A}$ & \\
\hline 5 & 123 & $\mathbf{P}$ & $\mathbf{N}$ & B & \\
\hline 6 & 122 & $\mathbf{L}$ & C & B & \\
\hline 7 & 121 & $\overline{\mathbf{P}}$ & $C \& N$ & $\mathbf{B}$ & \\
\hline 8 & 120 & $\mathbf{L}$ & $\mathbf{N}$ & C & \\
\hline 9 & 115 & $\mathbf{P}$ & $C \& N$ & B & \\
\hline 10 & 110 & $\mathbf{L}$ & $C \& N$ & B & Inhibition \\
\hline 11 & 100 & $\mathbf{E}$ & C & $\mathbf{A}$ & \\
\hline 12 & 95 & $\mathbf{L}$ & C & B & Inhibition \\
\hline 13 & 92 & $\mathbf{P}$ & $\mathbf{N}$ & C & \\
\hline 14 & 86 & $\mathbf{P}$ & C & C & \\
\hline 15 & 78 & $\mathbf{P}$ & $\mathbf{C}$ & C & \\
\hline 16 & 75 & $\mathbf{E}$ & $\mathbf{N} \& \mathbf{C}$ & B & \\
\hline 17 & 72 & $\mathbf{P}$ & C & C & \\
\hline 18 & 68 & $\mathbf{P}$ & $C \& N$ & B & \\
\hline 19 & 62 & $\mathbf{E}$ & $\mathbf{N}$ & B & \\
\hline 20 & 58 & $\overrightarrow{\mathbf{P}}$ & C & $\bar{C}$ & \\
\hline 21 & 56 & L & $\mathbf{N}$ & C & Inhibition \\
\hline 22 & 52 & $\mathbf{P}$ & $C \& N$ & C & \\
\hline 23 & 50 & $\mathbf{P}$ & $C \& \mathbf{N}$ & $\mathbf{A}$ & \\
\hline 24 & 48 & $\mathbf{E}$ & $C \& \mathbf{N}$ & C & \\
\hline 25 & 41 & $\overrightarrow{\mathbf{P}}$ & C & C & \\
\hline 26 & 30 & $\mathbf{E}$ & C & $\mathbf{A}$ & \\
\hline 27 & 26 & $\mathbf{E}$ & C & C & \\
\hline 28 & 22 & $\mathbf{P}$ & C & C & \\
\hline 29 & 21 & $\mathbf{P}$ & $C \& \mathbf{N}$ & C & \\
\hline
\end{tabular}

${ }^{a} E$, Early; $L$, late; I, intermediate; $P$, persistent.

${ }^{b} \mathrm{~N}$, Nucleus; C, cytoplasm.

'A, Level of synthesis decreased after appearance; B, level of synthesis remained steady; $C$, level of synthesis increased.

proteins, which were synthesized as early as $6 \mathrm{~h}$ after infection. This class consisted of eight proteins having molecular weights from 140,000 to 26,000 . The second class, the intermediate proteins, consisted of two proteins having molecular weights of 155,000 and 145,000 ; these appeared $9 \mathrm{~h}$ after infection. The late class contained five proteins having molecular weights from 122,000 to 56,000 ; these appeared no sooner than $12 \mathrm{~h}$ after infection.

The patterns of protein synthesis were seen in both the cytoplasmic extract (Fig. 3) and the solubilized nuclei (Fig. 4). The location of some polypeptides in the nuclei specifically suggests rapid transport of these proteins across the nuclear membrane. Figures 3 and 4 compare Coomassie brilliant blue-stained gels (Fig. 3A and 4A), which show total protein profiles, and autoradiograms (Fig. 3B and 4B), which show actively synthesized proteins. For example, proteins 3 and 11 were lightly stained at $6 \mathrm{~h}$ (Fig. 3A), but intensely labeled (Fig. 3B). Protein $H$ was present throughout the infection (Fig. 3A), but incorporated $\left.{ }^{35} \mathrm{~S}\right]$ methionine was present only during the first $6 \mathrm{~h}$ (Fig. 3B). 


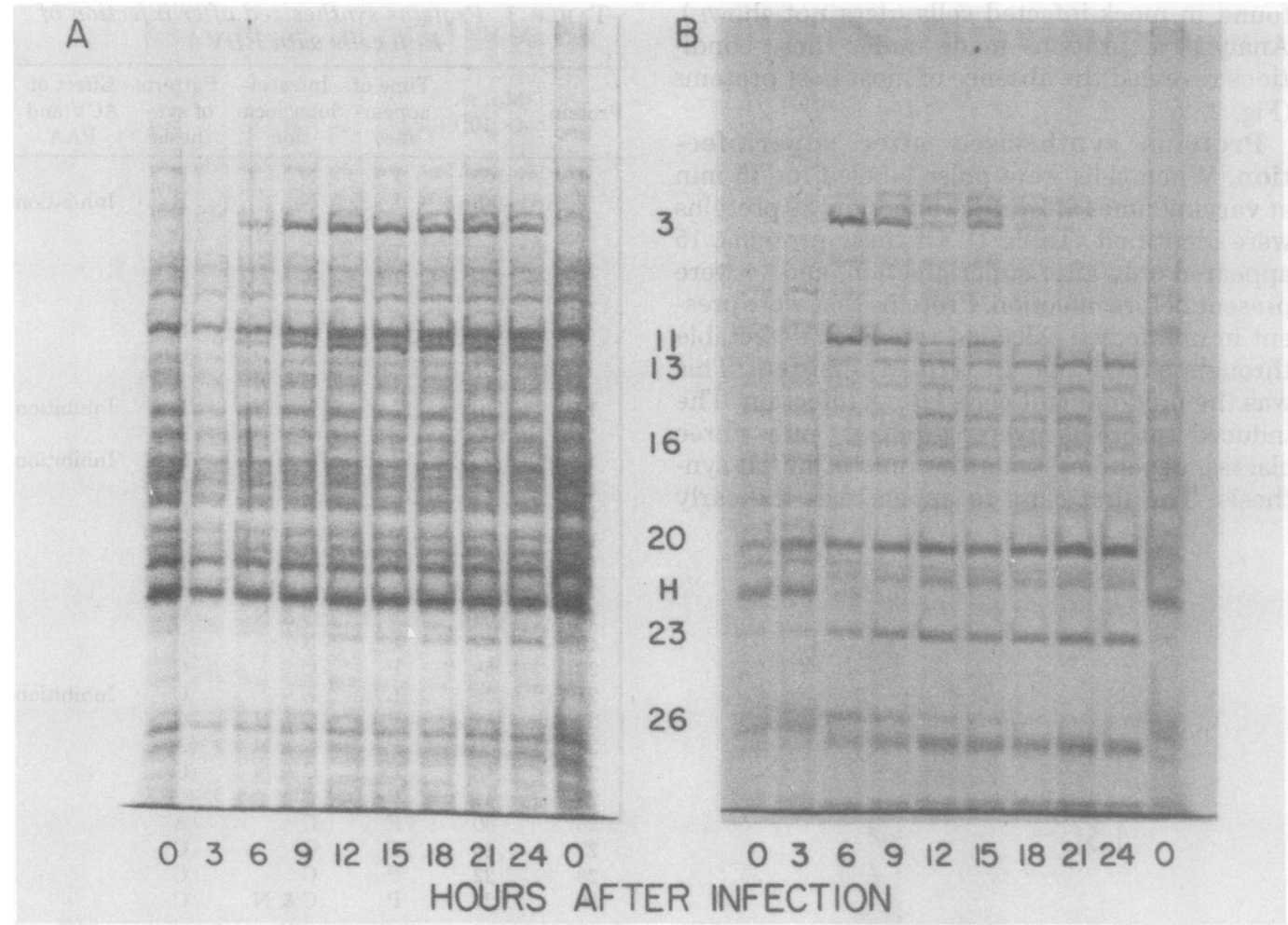

Fig. 3. Time course of appearance of virus-induced proteins in cytoplasm of superinfected Raji cells. The rates of synthesis as determined by incorporation of $\left[{ }^{35} S\right]$ methionine were not related to the amounts of protein present in cell extracts as determined by protein staining. Cells were pulse-labeled for 15 min at the times indicated after infection. The numbers between gels $(A)$ and $(B)$ correspond to the protein designations in Table 1. (A) Coomassie brilliant blue-stained gel. (B) Autoradiograph of same gel.

These proteins can be further characterized by the pattern of synthesis after the initial appearance. Type $A$ proteins are those which, after initial high rates of synthesis, had decreased rates of synthesis later in infection. This type is exemplified by proteins 3 and 11 (Table 1). Type $B$ proteins had relatively stable levels of synthesis after appearance; proteins 1 and 2 reflect this type of synthesis. These proteins were equally labeled from 9 to $21 \mathrm{~h}$ after infection. Type C proteins are those proteins which had increased levels of synthesis after superinfection; proteins 13 and 26 represent this type. The time of appearance did not reflect the pattern of synthesis; in the early group of proteins, there were A, B, and $\mathbf{C}$ types.

When the stained gels were examined (Fig. 3A and 4A), there was very little detectable difference in the protein patterns at different times after infection. Only virus-induced proteins 1, 2, 3 , and 11 appeared upon staining.

Intracellular location of proteins synthesized after superinfection. Proteins which were newly synthesized after superinfection appeared in both the nuclei and the cytoplasm (Fig. 3 through 5). Some proteins were immediately transported to the nucleus, whereas others appeared to have no detectable exchange between the cytoplasm and nucleus for at least 26 $h$ after infection. When proteins were pulsed at $7 \mathrm{~h}$ postinfection and then incubated in unlabeled media, there was no indication that cytoplasmic proteins migrated into the nucleus or that nuclear proteins moved into the cytoplasm (Fig. 5), except for those polypeptides which showed rapid transport. Also, at the time of labeling ( $7 \mathrm{~h}$ postinfection) protein 3 was not made. After synthesis, the proteins apparently stabilized intracellularly. There was no indication of degradation of virus-induced proteins over the time period studied. It further appears that there was no post-translational processing of the proteins unless this processing occurred extremely rapidly after synthesis. The complete absence of protein 3 in Fig. 5 is indicative of a very low rate of synthesis at $7 \mathrm{~h}$ after infection. 
Fate of host proteins. Although most of the host protein synthesis ceased about $6 \mathrm{~h}$ after infection (Fig. 3 and 4), there was no indication of degradation of host proteins (Fig. 6). After uninfected cells were labeled for 24 h before infection and then at varying intervals thereafter the labeled proteins were analyzed by electrophoresis followed by autoradiography, the host protein patterns were identical. Many host proteins showed continued synthesis during the first $6 \mathrm{~h}$ after infection; therefore, degradation of preexisting proteins could not be determined by staining alone because new synthesis may have obscured any degradation. Although the stained gel showed the appearance of virus-induced proteins, none of these proteins was labeled (data not shown). Preexisting host proteins which were detected by this method were neither degraded nor modified by the infection. Therefore, virus-induced proteins probably do not require a salvage pathway of host amino acids for synthesis. Fig. 6, lane M24 shows the mock-infected cell protein pattern $24 \mathrm{~h}$ after addition of virus to the other cell sample. There was no detectable difference in the gel patterns; however, there may have been minor changes which did not affect mobility noticeably.
Effect of inhibitors of viral DNA replication on protein synthesis. When either PAA or ACV was added $2 \mathrm{~h}$ after infection and left throughout the infectious cycle, at least four polypeptides were inhibited (Fig. 7 and Table 1). Protein 2, which was synthesized at an intermediate time, disappeared completely. At least three other proteins (proteins 10, 12, and 21) were apparently partially inhibited by both drugs; these proteins were normally synthesized late in infection. These drugs had no detectable effects on protein synthesis in mock-infected cells. The patterns were identical for both PAAand ACV-treated superinfected cells (Fig. 7A and B). There was no detectable effect on protein synthesis in ACV-treated, mock-infected cells (Fig. 7C).

Phosphorylation of proteins in superinfected cells. There were six virus-induced phosphoproteins which did not correspond to proteins present before infection. The pattern of appearance of these proteins apparently reflected a degree of controlled phosphorylation. At $6 \mathrm{~h}$ after infection, protein $18 \mathrm{P}$ was intensively phosphorylated (Fig. 8 and Table 2) and then was decreasingly phosphorylated later in infection. Proteins 16P and 19P appeared to

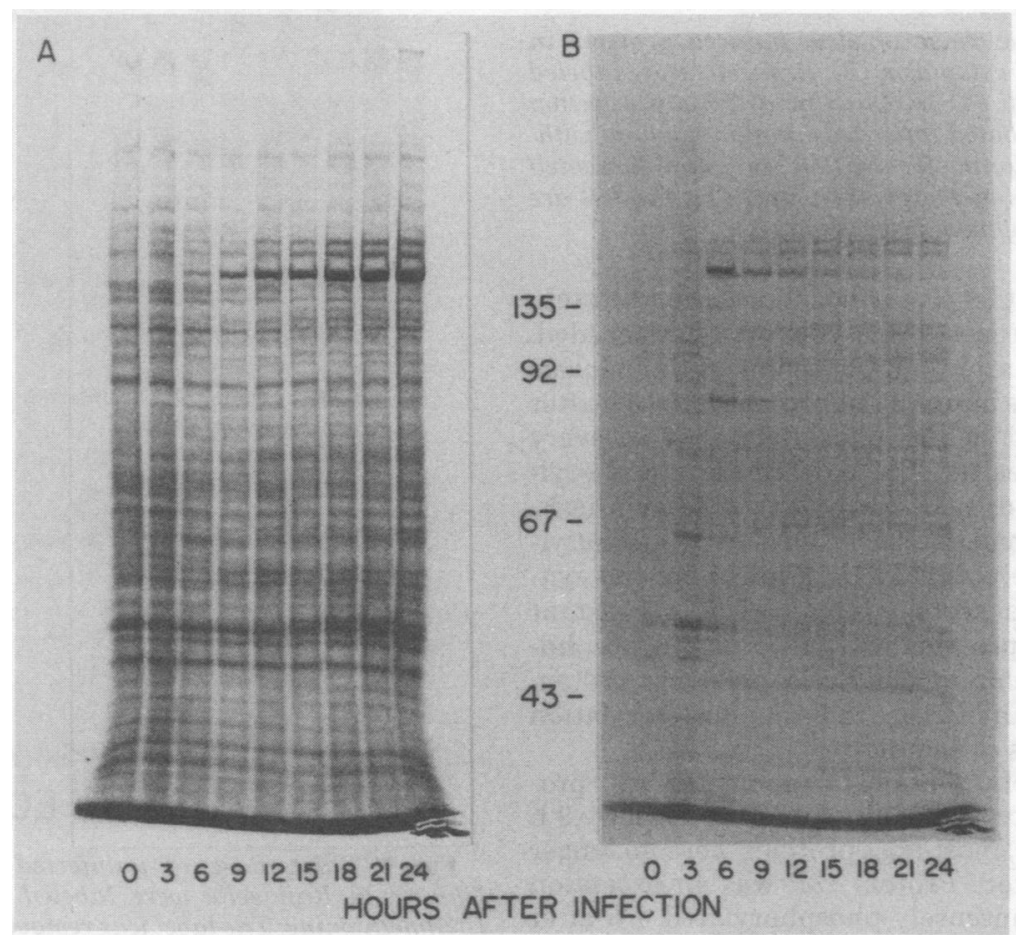

FIG. 4. Time course of appearance of virus-induced proteins in nuclei of superinfected Raji cells. Cells were pulse-labeled with ${ }^{36}$ S ] methionine as described in the legend to Fig. 3. The nuclei were prepared as described in the text. (A) Coomassie brilliant blue-stained gel. (B) Autoradiograph of same gel. 


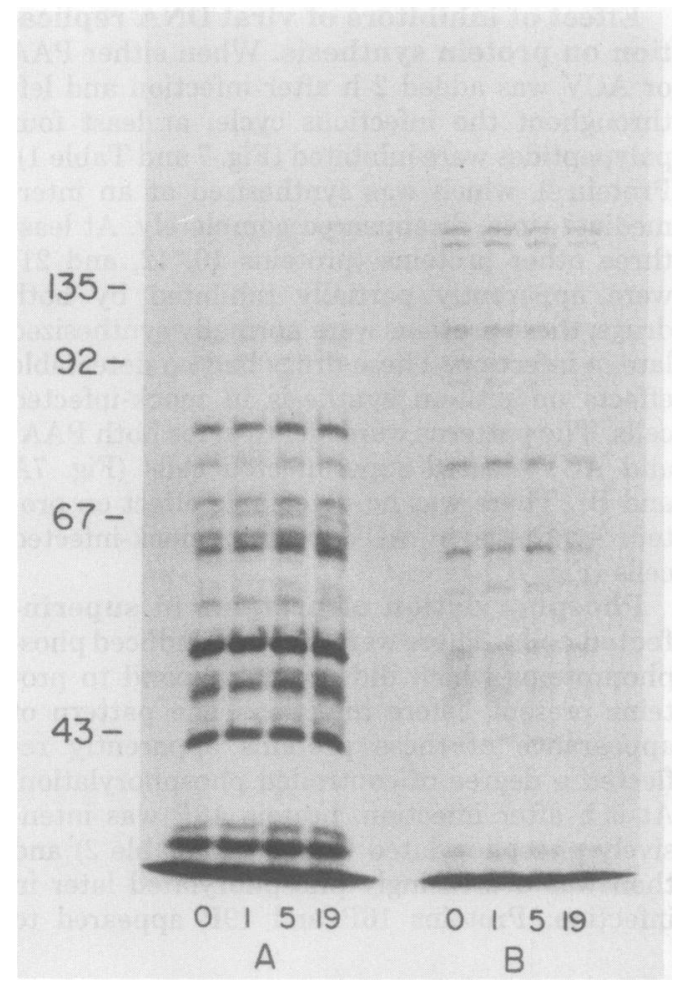

Fig. 5. Pulse-chase of virus-induced proteins in nuclei (A) and cytoplasm (B). Raji cells were labeled for 20 min with $\left[{ }^{36} S\right]$ methionine at $7 h$ postinfection and then incubated (after washing) in medium without $\left[{ }^{35} S\right]$ methionine for the time (in hours) indicated at the bottoms of the gels. Numbers on the left are molecular weights of markers $\left(\times 10^{3}\right)$.

have constant levels of phosphorylation. Protein $21 \mathrm{P}$ had increased levels as infection proceeded. Protein 13P, a protein persistent in the nucleus (Table 1), was intensely phosphorylated $3 \mathrm{~h}$ after infection and lightly phosphorylated at every interval thereafter. The patterns of phosphorylation were not necessarily linked to synthesis. Protein 18P had decreased levels of phosphorylation at time points later in infection; the synthesis of this protein remained at a constant level. Other proteins had patterns of phosphorylation similar to synthesis patterns; protein 22P showed an increase in both phosphorylation and synthesis over time.

The phosphorylation of uninfected cell proteins also decreased after superinfection; by $9 \mathrm{~h}$ postinfection, most host proteins were no longer phosphorylated. Protein 13P was an exception since it was intensely phosphorylated $3 \mathrm{~h}$ after infection and then to a lesser degree thereafter. The phosphoproteins were present in lesser amounts in the cytoplasm (Fig. 9), and some of the nuclear phosphoproteins were absent. Although proteins labeled with $\left.{ }^{35} \mathrm{~S}\right]$ methionine and ${ }^{32} \mathrm{P}$ had identical molecular weights under these conditions, this does not mean that they are the same protein. Two or more proteins may have been present; one may have been newly synthesized and labeled with $\left[{ }^{35}\right.$ S]methionine, whereas another may have been phosphorylated without de novo synthesis. This distinction is noted by the addition of the suffix $P$ to the protein number.

\section{DISCUSSION}

Before superinfection, the human lympho-

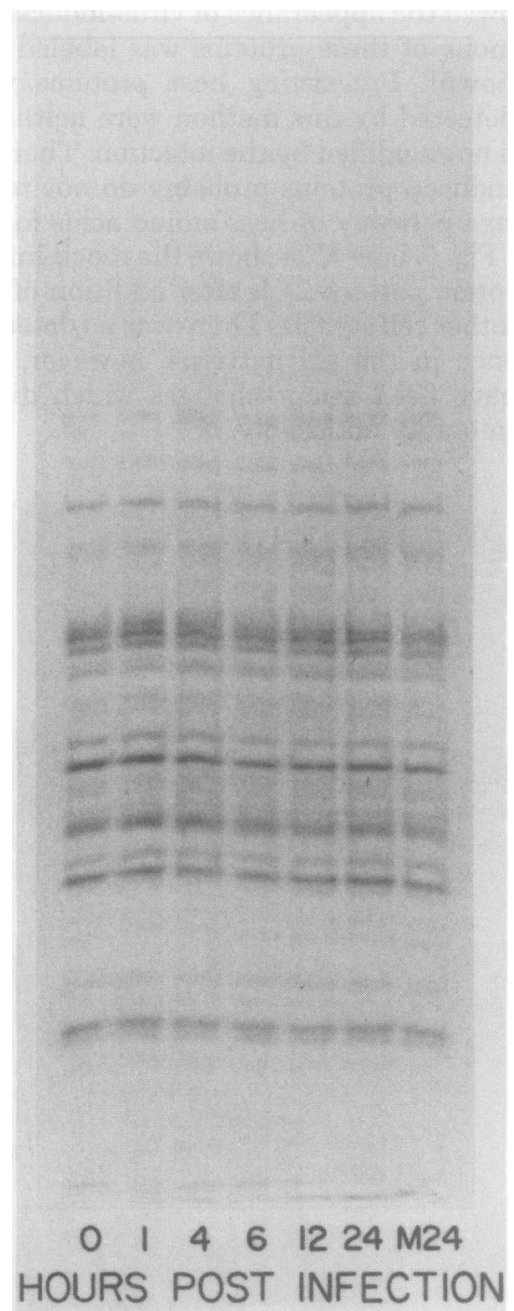

Fic. 6. Pulse-chase of uninfected cell proteins. Uninfected Raji cells were labeled for $24 h$ with $\left.{ }^{35} \mathrm{~S}\right]$ methionine. The label was removed and the cells were incubated for $1 \mathrm{~h}$ in medium without $\left[{ }^{35} S\right] \mathrm{me}$ thionine before infection. Cells were harvested at the indicated times after infection. 


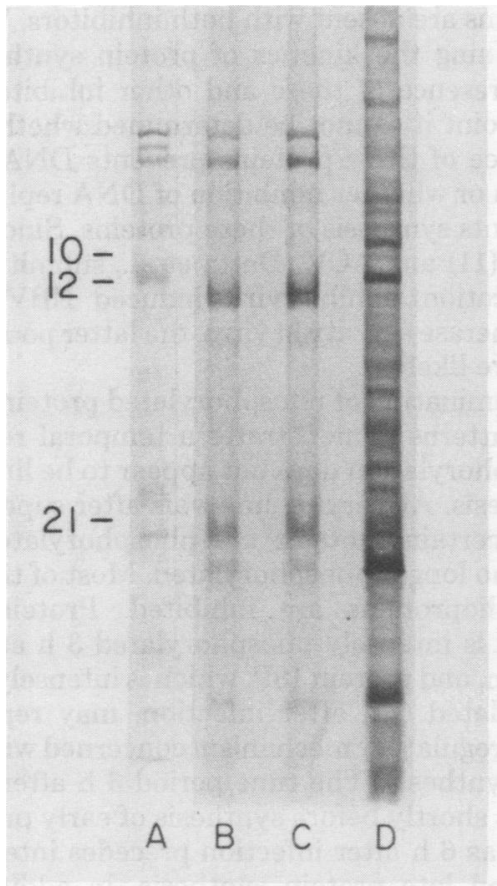

Fig. 7. Effect of DNA replication inhibitors on protein synthesis. The viral DNA replication inhibitors PAA (lane B) and ACV (lane C) were added to superinfected Raji cells as described in the text. Uninfected cells (lane A) and mock-infected cells (lane D) were also treated with $A C V$. The numbers on the left correspond to the protein designations in Table 1 and indicate the missing bands.

blastoid cell line Raji carries latent EBV genomes and does express at least one viral gene product, namely EBV-determined nuclear antigen (5). After superinfection of Raji cells by EBV, the bulk of host protein synthesis is blocked, some preexisting proteins that may be either host or viral proteins persist, and 15 new viral proteins are induced. The virus-induced proteins are synthesized at different times after infection and have different patterns of synthesis. For example, the synthesis of some early proteins ceases at late stages in infection. This result suggests that only part of the genome is active at certain times after infection. In addition to three types of virus-induced proteins, there is a fourth class of proteins which is present in the cells before infection. The synthesis of persistent proteins is in some cases stimulated by viral infection. There is at least some superficial similarity to the herpes simplex virus type 1 cascade regulation of $\alpha, \beta$, and $\gamma$ classes of proteins in the temporal sequence of appearance of various proteins (6). However, there are variations which appear to be unique to EBV. These in- clude the continued synthesis at a constant rate of certain virus-induced proteins after their initial appearance, rather than at diminishing rates. Also, unlike herpes simplex virus, some proteins present before infection are continually synthesized and in some cases are stimulated. These persistent cellular proteins may be products of the viral genome since viral antigens, such as EBV-determined nuclear antigen, can be detected in Raji cells before infection, or they may be host-specified proteins which are required for virus production.

The 29 proteins which are synthesized in detectable amounts after superinfection at varying times undoubtedly include both structural and nonstructural proteins. It has been reported that

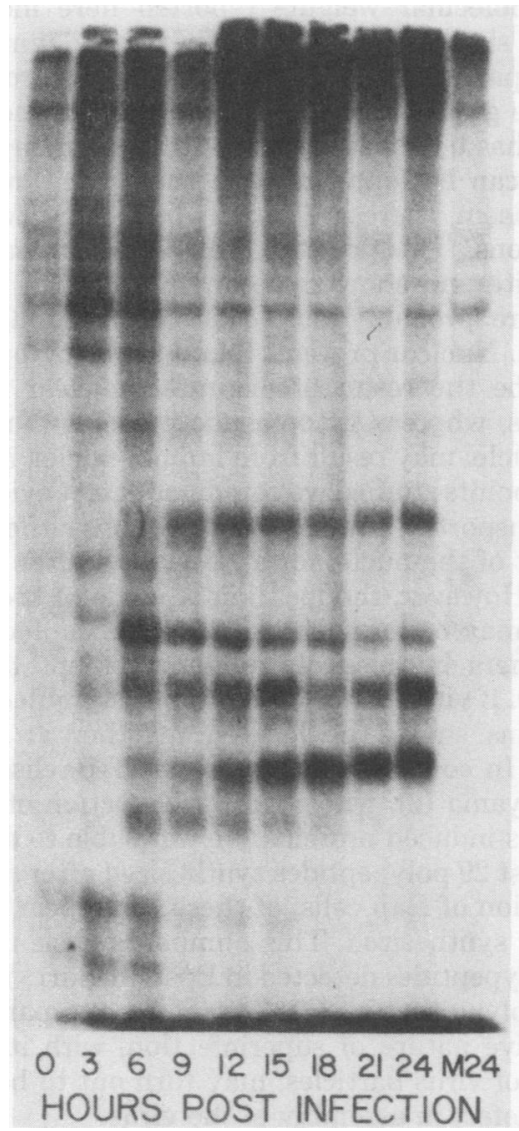

Fig. 8. Virus-induced phosphorylation of nuclear proteins after superinfection. At the indicated times after infection, Raji cells were harvested and incubated in phosphate-free medium containing ${ }^{32} P_{i}$ for 15 min. They were harvested and fractionated into cytoplasm and nuclei as described in the text. After electrophoresis, autoradiography was performed on the gels. Lane M24, Pattern of mock-infected cells labeled $24 \mathrm{~h}$ after the medium was changed. 
TABLE 2. Appearance of phosphoproteins after infection of Raji cells with $E B V$

\begin{tabular}{cccll}
\hline Protein & $\begin{array}{c}\text { Mol wt } \\
\left(\times 10^{3}\right)\end{array}$ & $\begin{array}{c}\text { Time of } \\
\text { initial ap- } \\
\text { pearance } \\
\text { (h) }\end{array}$ & $\begin{array}{c}\text { Pattern of } \\
\text { phosphoryla- } \\
\text { tion }\end{array}$ & $\begin{array}{c}\text { Intracellu- } \\
\text { lar } \\
\text { location }^{a}\end{array}$ \\
\hline $13 P$ & 92 & 0 & Decreased & N \\
$16 P$ & 75 & 9 & Level & N \& C \\
$18 P$ & 68 & 6 & Decreased & N \& C \\
$19 P$ & 62 & 3 & Level & N \\
$22 P$ & 52 & 6 & Increased & N \& C \\
$24 P$ & 48 & 6 & Decreased & N \& C \\
27P & 26 & 6 & Decreased & N \& C \\
\hline
\end{tabular}

${ }^{a}$ N, Nucleus; C, cytoplasm.

there are 33 proteins in EBV particles (4). Comparisons of the reported molecular weights with the molecular weights reported here indicate some similarities. We are currently purifying virus particles in order to compare the proteins.

The gross intracellular location of these proteins has been determined. Although many proteins can be found in both the nuclei and the cytoplasm, there are some which have defined locations. The proteins which predominate at one site and show trace amounts in the other site are probably the result of the lability of nuclei. Nuclear proteins found in the cytoplasm may be the result of disrupted nuclear membranes, whereas cytoplasmic proteins found in the nuclei may result from impure nuclei. At the time points studied we could not detect evidence of transport of virus-induced proteins either into or out of the nuclei for at least $26 \mathrm{~h}$ after infection. However, the location of some of the proteins may be more transitory than the location of others because of rapid movement to the nuclei. If virus particles are to be assembled, the proteins should be located together at some time. In contrast to the results of Bayliss and Nonoyama (2), who reported detection of only 9 virus-induced proteins, we were able to detect at least 29 polypeptides synthesized after superinfection of Raji cells; of these, 15 appear to be newly synthesized. This number is close to the 33 polypeptides detected in Epstein-Barr virions by Dolynuik et al. (4). Therefore, the partially abortive nature of superinfection, with its low yield of virus particles, may turn out to be due to a defect in assembly of the virus.

At no point after infection does the pattern of prelabeled uninfected cell proteins change. This result indicates a lack of detectable degradation of host proteins and an absence of modification of preexisting protein mobility by viral infection.

With the inhibitors of EBV DNA replication ACV (3a) and PAA (13), the protein patterns of infected cells appear to be identical; the same proteins are absent with both inhibitors. We are examining the kinetics of protein synthesis in the presence of these and other inhibitors. At this point it cannot be determined whether the absence of these proteins prevents DNA replication or whether inhibition of DNA replication prevents synthesis of these proteins. Since both PAA (11) and ACV (Datta et al., submitted for publication) inhibit virus-induced EBV DNA polymerase activity in vitro, the latter possibility is more likely.

Examination of phosphorylated protein banding patterns demonstrates a temporal relation. Phosphorylation does not appear to be linked to synthesis. At varying intervals after superinfection, certain proteins are phosphorylated and then no longer phosphorylated. Most of the host phosphoproteins are inhibited. Protein 13P, which is intensely phosphorylated $3 \mathrm{~h}$ after infection, and protein $18 \mathrm{P}$, which is intensely phosphorylated $6 \mathrm{~h}$ after infection, may represent some regulatory mechanism concerned with protein synthesis. The time period $3 \mathrm{~h}$ after infection is shortly before synthesis of early proteins, whereas $6 \mathrm{~h}$ after infection precedes intermediate and late protein synthesis, in addition to DNA replication.

Evidence supporting the role of protein kinase activity in other transforming systems (8) has

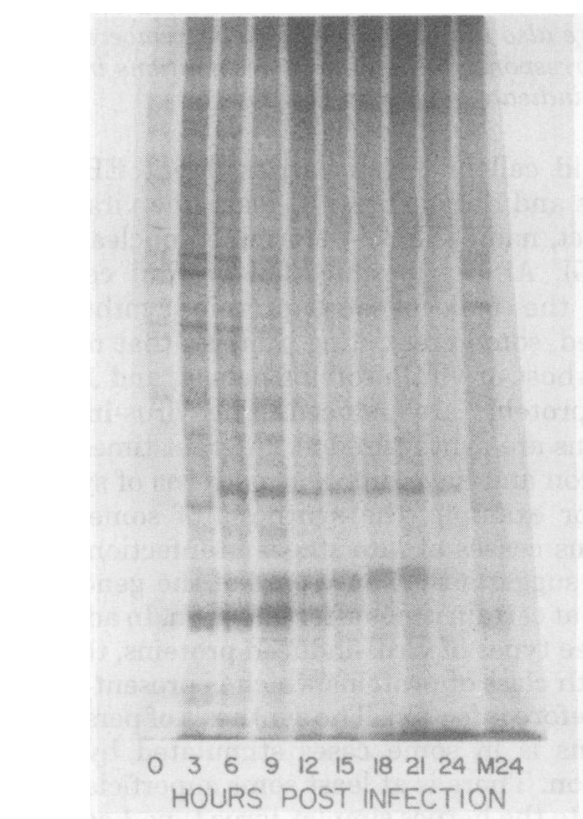

FIG. 9. Virus-induced phosphorylation of cytoplasmic proteins. Infected cells were labeled with ${ }^{32} P_{i}$ as described in the legend to Fig. 8 and electrophoresed. 
been demonstrated. Additionally, since protein $13 \mathrm{P}$ is present in uninfected cells, it may be a host gene product. The host cell may play a role in determining whether transformation or lysis is the result of virus infection. Whether the protein phosphorylations are phosphorylations of virus-produced proteins or altered phosphorylations of host proteins has yet to be shown. Since the first possibility requires new protein synthesis and the second does not, it should be possible to resolve this question.

We have demonstrated sequential synthesis of EBV-induced proteins. When viral DNA replication is blocked, certain proteins are inhibited. There is also a temporal sequence of protein phosphorylation. The mode of regulation of these diverse processes is currently under investigation.

\section{ACKNOWLEDGMENTS}

R.J.F. was supported by National Research Service Training Fellowship grant 5-T32-CA09156. This study was supported in part by Public Health Service grant CA19014 from the National Cancer Institute (DNA, Virus Genomes and Oncogenesis).

We thank Joel Kostyu for technical help, Etsuyo I. Choi for artwork, Kay Faison for typing, G. Elion for the gift of ACV, and Alok K. Datta for critical reading of the manuscript. We thank especially James Shaw for helpful discussion.

\section{LTERATURE CITED}

1. Adams, A. 1975. Preparation of Epstein-Barr virus from P3HR-1 cells and isolation of virus DNA, p. 129-146. In D. V. Ablashi, H. G. Aaslestad, and G. de Thé (ed.), Epstein-Barr virus, production, concentration, and purification. International Agency for Research on Cancer, Lyon, France.

2. Bayliss, G. J., and M. Nonoyama. 1978. Mechanisms of infection with Epstein-Barr virus. III. The synthesis of proteins in superinfected Raji cells. Virology 87:204207.

3. Bonner, W. M., and R. A. Laskey. 1974. A film detection method for tritium-labelled proteins and nucleic acids in polyacrylamide gels. Eur. J. Biochem. 46:83-88.

3a.Colby, B. M., J. E. Shaw, G. B. Elion, and J. S. Pagano. 1980. Effect of acyclovir [9-(2-hydroxyethoxymethyl)guanine] on Epstein-Barr virus DNA replication. J. Virol. 34:560-568.

4. Dolynuilk, M., R. Pritchett, and E. Kieff. 1976. Proteins of Epstein-Barr virus. I. Analysis of the polypeptides of purified enveloped Epstein-Barr virus. J. Virol. 17:935949.

5. Fresen, K. O., and H. Zur Hausen. 1976. Establishment of EBNA-expressing cell lines by infection of EpsteinBarr virus (EBV)-genome-negative human lymphoma cells with different EBV strains. Int. J. Cancer 17:161166.

6. Honess, R. W., and B. Roirman. 1974. Regulation of herpesvirus macromolecular synthesis. I. Cascade regulation of the synthesis of three groups of viral proteins. J. Virol. 14:8-10.

7. Laemmli, U. K. 1970. Cleavage of structural proteins during the assembly of the head of bacteriophage T4. Nature (London) 227:680-685.

8. Levinson, A. D., H. Oppermann, L. Levintow, H. E. Varmus, and J. M. Bishop. 1978. Evidence that the transforming gene of avian sarcoma virus encodes a protein kinase associated with a phosphoprotein. Cell 15:561-572.

9. Lin, J. C., J. E. Shaw, M. C. Smith, and J. S. Pagano. 1979. Effect of 12-O-tetradecanoyl-phorbal-13-acetate on the replication of Epstein-Barr virus. I. Characterization of viral DNA. Virology 99:183-187.

10. Lowry, O. H., N. J. Rosebrough, A. L. Farr, and R. J. Randall. 1951. Protein measurement with the Folin phenol reagent. J. Biol. Chem. 193:265-275.

11. Ooka, T., G. Lenoir, and J. Daille. 1979. Characterization of an Epstein-Barr virus-induced DNA polymerase. J. Virol. 29:1-10.

12. Shaw, J. E., T. Seebeck, J.-L. H. Li, and J. S. Pagano. 1977. Epstein-Barr virus DNA synthesized in superinfected Raji cells. Virology 77:762-771.

13. Summers, W. C., and G. Klein. 1976. Inhibition of Epstein-Barr virus DNA synthesis and late gene expression by phosphonoacetic acid. J. Virol. 18:151-155.

14. Weber, K., and M. Osborn. 1969. The reliability of molecular weight determinations by dodecyl sulfatepolyacrylamide gel electrophoresis. J. Biol. Chem. 244: 4406-4412.

15. Zur Hausen, H., F. J. O'Neill, and U. K. Freese. 1978. Persisting oncogenic herpesvirus induced by the tumor promoter TPA. Nature (London) 272:373-375. 